\title{
ANALISIS TINGKAT KEPUASAN PENGGUNA TERHADAP PENERAPAN APLIKASI SISKEUDES DI KABUPATEN BANYUASIN SUMATERA SELATAN
}

\author{
Mardiana $^{1}$, Eka Hartati ${ }^{2}$ \\ 1,2Program Studi Sistem Informasi, STMIK Palcomtech, Palembang \\ Jln. Basuki Rahmat No.05, Palembang 30129, Indonesia \\ E-mail: ${ }^{1}$ mardiana@palcomtech.ac.id, ${ }^{2}$ eka_hartati@palcomtech.ac.id
}

\begin{abstract}
ABSTRAK
SISKEUDES merupakan aplikasi keuangan desa yang mulai dikembangkan pada tahun 2015 oleh Badan Pengawasan Keuangan dan Pembangunan (BPKP). Kabupaten Banyuasin telah menerapkan SISKEUDES, dan pada tahun 2017 sebanyak 227 desa yang telah menggunakan sistem ini. Penerapan SISKEUDES dengan tingkat kepuasan pengguna dapat menentukan keberhasilan dari penerapan sistem SISKEUDES itu sendiri. Penelitian ini mengambil sampel di kabupaten Banyuasin provinsi Sumatera Selatan. Tujuan dari penelitian ini menganalisis tingkat kepuasan pengguna terhadap penerapan aplikasi SISKEUDES dengan menggunakan regresi linear berganda. Metode penelitian ini menggunakan metode statistik deskriptif dengan penerapan model Green - Pearson yang terdiri dari variabel Easy of Use, Customization, Download Delay, dan Content. Penelitian ini menggunakan alat ukur berupa kuesioner yang terdiri dari 93 responden dari sembilan belas kecamatan yang ada di kabupaten Banyuasin, dimana skala pengukuran yang digunakan berupa skala likert dan analisis data dilakukan pengujian validitas, reabilitas dan regresi berganda. Hasil dari penelitian mendapatkan Persamaan regresi $\mathrm{Y}=-0,4.727+$ $0,1.050 \mathrm{X} 1+0,1.222 \mathrm{X} 2+-0,082 \mathrm{X} 3+0,042 \mathrm{X} 4$. Pada variabel X2 dan X2 berpengaruh secara signifikan terhadap variabel $\mathrm{Y}$, sedangkan variabel $\mathrm{X} 3$ dan $\mathrm{X} 4$ tidak berpengaruh terhadap variabel $\mathrm{Y}$.
\end{abstract}

Kata Kunci: SISKEUDES, Mudah digunakan, Kustomisasi, Unduh delay, Konten

\section{ABSTRACT}

SISKEUDES is a village finance application that was developed in 2015 by the Financial and Development Supervisory Agency. Banyuasin District has implemented SISKEUDES, and in 2017 as many as 227 villages have used this system. The application of SISKEUDES with the level of user satisfaction can determine the success of the implementation of the SISKEUDES system itself. This study took a sample in Banyuasin district, South Sumatra province. The aim of the study analyzes the level of user satisfaction in the application of SISKEUDES using multiple linear regression. In this study, researchers used quantitative research methods with the application of the Green-Pearson model consisting of Easy of Use, Customization, Download Delay, and Content variables. This study uses a questionnaire measuring device consisting of 93 respondents from nineteen districts in Banyuasin district, where the measurement scale used is a Likert scale and data analysis is tested for validity, reliability and multiple regression. The results of the study get the regression equation $Y=-0.4 .727+0.1 .050 X 1+0.1 .222 X 2+-0.082 X 3$ +0.042 X4. The variables X1 and X2 significantly influence the variable $Y$, while the variables X3 and X4 have no effect on the variable $Y$.

\section{Keywords: SISKEUDES, Easy of Use, Customization, Download Delay, Content}

Author Korespondensi (Eka Hartati)

Email : eka_hartati@palcomtech.ac.id

\section{PENDAHULUAN}

Desa adalah bagian dari pemerintahan yang ada di sebuah kabupaten, dalam setiap pelaksanaan kegiatan desa menerapkan konsep desentralisasi dimana setiap arahan berasal dari pemerintah pusat. Menurut undang-undang nomor 12 Tahun 2008 menetapkan bahwa desa adalah kesatuan masyarakat hukum yang memiliki kewenangan untuk mengatur dan mengurus kepentingan masyarakat setempat berdasarkan asal usul dan adat istiadat setempat yang diakui dalam sistem pemerintahan nasional dan berada di daerah kabupaten [1]. Setiap kegiatan yang terkait Keuangan Desa merupakan kewajiban dari desa itu sendiri dalam proses perencanaan, pelaksanaan, penatausahaan, pelaporan, dan 
pertanggungjawaban keuangan desa. Rencana Kerja Pemerintah Desa (RKPDesa) yaitu penjabaran dari Rencana Pembangunan Jangka Menengah Desa dalam waktu 1 tahun. Anggaran Pendapatan dan Belanja Desa (APBDesa) adalah rencana dari sebuah keuangan tahunan Pemerintahan Desa. Diperlukan Peraturan Bupati/Walikota untuk mengatur mengenai Pengelolaan Keuangan Desa. SISKEUDES merupakan aplikasi keuangan desa yang mulai dikembangkan pada tahun 2015 oleh Badan Pengawasan Keuangan dan Pembangunan (BPKP). Kementerian Dalam Negeri (Mendagri) dan Kemendesa PDTT bekerja sama untuk penerapan aplikasi SISKEUDES di setiap desa di Indonesia untuk mempermudah proses pengelolaan keuangan khusus untuk desa yang terdiri dari Perencanaan, Penganggaran, Penatausahaan, Pembukuan, dan Pelaporan. Dalam penerapannya, Aplikasi SISKEUDES dapat memberikan kemudahan bagi Kepala Desa untuk membuat laporan keuangan desa tiap semester dan memberikan kemudahan bagi operator desa dalam mencatat laporan kekayaan desanya apabila desa tersebut sudah otomatis tercatat melakukan penatausahaan.

Aplikasi SISKEUDES telah melakukan akomodir terhadap seluruh regulasi yang terkait dengan keuangan desa, selanjutnya dirancang dengan terintegrasi, user friendly, dan apliaksi dekstop, serta memiliki sistem pengendalian secara intern dan efektif dalam menghasilkan sebuhan informasi keuangan [2]. Pada penelitian sebelumnya, aplikasi keuangan desa telah menggunakan database yaitu database Microsoft Access legibh portable dan mudah digunakan oleh pengguna [3]. Hanya sistem operasi windows yang dapat digunakan dan mengiplmentasikan SISKEUDES. Pada gambar 1 merupakan fitur dari aplikasi SISKEUDES:

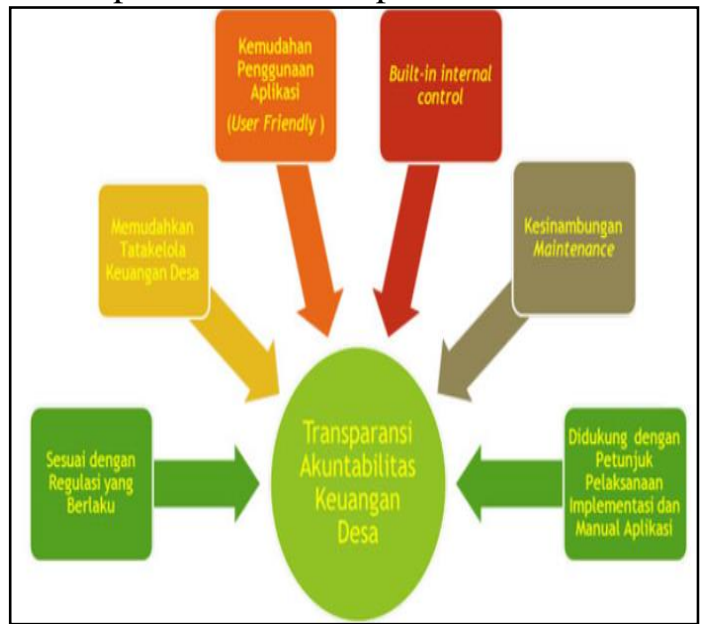

Gambar 1. Fitur Aplikasi SISKEUDES

(Sumber: updesa.com)

Kabupaten Banyuasin telah menerapkan SISKEUDES, dan pada tahun 2017 sebanyak 227 desa yang telah menggunakan sistem ini. Penerapan SISKEUDES dengan tingkat kepuasan pengguna dapat menentukan keberhasilan dari penerapan sistem SISKEUDES itu sendiri.

Tingkat kepuasaan pengguna pada suatu perangkat dapat diukur dengan berbagai faktor salah satunya dengan menggunakan model tingkat kepuasaan dari Green-Pearson yang merumuskan empat (4) variable yang terdiri dari: Kemudahan (Easy of Use / Ease of Navigation), Personalisasi (Customization), Kecepatan akses pada aplikasi (DownloadDelay), Penyajian Informasi (Content).

Penelitan dengan judul Pengukuran Tingkat Kertergunaan (Usability) Sistem Informasi Keuangan dengan menggunakan metode Usability yang terdiri dari learnability, effisiency, memorability, error dan satisfaction. Tujuan dari penelitian ini untuk melakukan pengukuran ketergunaan seberapa besar kesulitan user dan tingkatan pemahaman dalam menggunakan sistem transaksi melalui antarmuka DuWit yang sudah dibuat. Dalam penelitian ini menghasilkan bahwa tinggkat ketergunaan dalam sistem Duwit mudah dipelajari, efsien, ketika pengguna melakukan interaksi langsung ke sistem duwit yang dimana tidak banyak melakukan kesalahan dan pengguna merasa nyaman. [4].

Penelitian selajutnya membahas mengenai kualitas layanan website LP2M UIN Raden Fatah Palembang dengan mengimplementasikan Webqual 4.0 dengan melakukan pengujian uji validitas dan reabilitas untuk mendapatkan data yang valid dan reabel. Peneliti menggunakan teknik analisis korelasi sederhana dengan mengajukan tiga hipotesisi. Hasil penelitian menunjukan bahwa ketiga hipotesis mempunyai hubungan yang signifikan pada kepuasan pengguna dengan korelasi antar variabel yang diteliti tergolong lemah posistif dan kontribusi seluruh variabel sebesar 44,1\% [5].

Dalam penelitian dengan judul analisis usabilitas sistem informasi driver PT. Gojek Indonesia berdasarkan pendekatan evaluasi usability heuristik dengan tujuan untuk mengetahui bahwa aplikasi tersebut sudah dapat diterima 
baik oleh masyarakat. Heuristik Evaluation (HE) digunakan sebagai metode untuk mencari masalah usabilitas sistem dengan melibatkan beberapa responden. Penelitian tersebut mendapakan hasil pada aplikasi driver gojek sudah cukup baik dilihat dari sisi desain antarmukanya untuk evaluasi usability heuristik, namun didalam kemudahan penggunaan usability menjadi lebih baik lagi. Mulai dari rule yang perlu ditingkatkan diantaranya adalah rule user control and freedom yang menekankan pada aspek pengguna dapat memilih pekerjaan sesuai kebutuhan serta rule help users regonize, diagnose, and recover form errors yang menekankan harusnya ada saran saat driver melakukan kesalahan [6].

Penelitian selanjutnya dengan judul analisis evaluasi aplikasi augmented reality untuk informasi kebudayaan bali berdasarkan standar ISO 25010. Tujuan penelitian ini untuk mengevaluasi dan menilai kualitas sebuah aplikasi berdasarkan ISO 25010. Adapun standar kualitas software yang diuji adalah aspek functional suitability, usability, performance efficiency, memorability, dan compatibility. Hasil dari penelitian ini dapat disimpulkan bahwa kualitas software yang mengacu kepada standar kualitas aplikasi Augmented Reality Museum Bali telah memenuhi standar kualitas software yang mengacu kepada standar ISO 25010. hasil pengujian aspek functional suitability adalah 100\% [7]. Adapun Tujuan dari penelitian ini untuk menganalisis tingkat kepuasan pengguna terhadap penerapan aplikasi SISKEUDES dengan menggunakan regresi linear berganda.

\section{METODOLOGI}

Penelitian 1: Pengukuran Aplikasi Siskuedes dengan Menggunakan Model Green - Pearson yang terdiri dari empat Variabel. Dalam penelitian ini peneliti menggunakan penelitian kuantitatif yang dimana penelitian yang menggunakan filsafat positivisme, dimana dalam meneliti menggunakan sampel tertentu dan data penelitiannya berupa angka-angka dengan menggunakan statistik. Prosedur kegiatan penelitian ini dijelaskan pada gambar 2 .

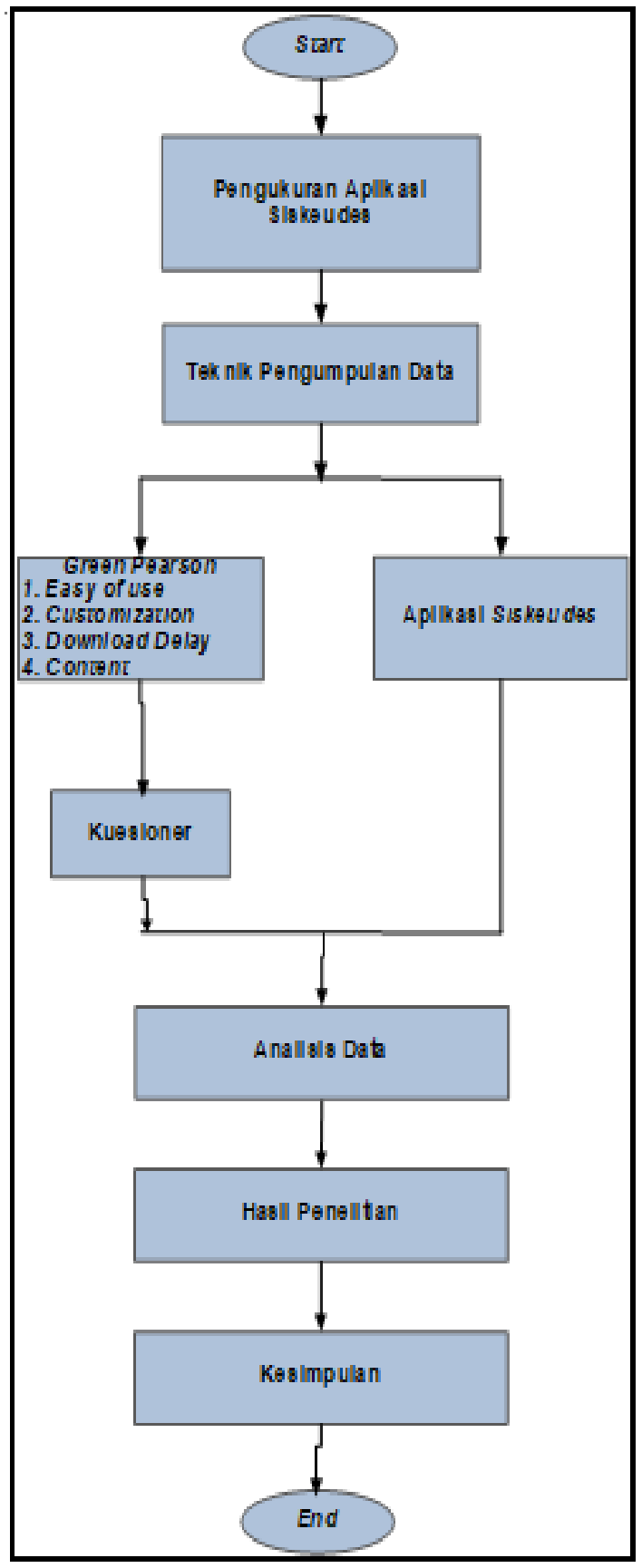

Gambar 2. Prosedur Kegiatan Penelitian

Adapun penjelasan dari prosedur kegiatan penelitian pada gambar 2 adalah sebagai berikut:

1. Teknik pengumpulan data

Teknik pengumpulan data dalam penelitian ini dimana peneliti melakukan observasi dan penyebaran kuesioner ke seluruh operator desa yang ada di Kabupaten Banyuasin.

2. Implementasi dari aplikasi SISKEUDES menggunakan alat ukur model Green Pearson yang terdiri dari empat variabel. 
3. Variabel user satisfaction terdiri dari empat dimensi yaitu Easy of use, Customization, Download Delay, dan Content.

4. Alat ukur yang digunakan dalam penelitian ini adalah kuesioner, yang memiliki jenis data ordinal, dan bentuk skala pengukuran menggunakan skala likert. Skala likert digunakan untuk mengukur sebuah sikap, pendapat, dan persepsi seseorang atau sekelompok orang mengenai sebuah fenomena sosial dalam sebuah penelitian, fenomena sosial ini akan ditetapkan secara spesifik oleh peneliti, yang kemudian disebut sebagai variabel penelitian.

5. Kuesioner disebarkan kepada 93 responden yang merupakan operator desa di setiap kecamatan kabupaten Banyuasin, kemudian hasil kuesioner dikumpulkan dan dilakukan analisa data yang terdiri dari cek validatas dan reabilitas serta pengujian regresi berganda terhadap kuesioner, hasil dari pengolahan data mendapatkan hasil penelitian yang berupa sebuah rekomendasi tentang perbaikan sistem SISKEUDES untuk Kementerian Desa.

\section{HASIL DAN PEMBAHASAN}

Aplikasi Siskeudes ini digunakan untuk mengelola data keuangan yang dikambangkan pada tahun 2015 oleh Bdan Pengawasan Keuangan dan Pembangunan mulai Aplikasi Computer Baset Test (BPKP). Pada penelitian ini peneliti mengambil sampel di Kabupaten Banyuasin Sumatera Selatan. Model Green Pearson digunakan dalam penelitian ini yang terdiri dari Easy of Use, Custamization, Download Delay, Content dan User Satisfaction. Dalam penelitian ini penelitin melakukan observasi dan penyebaran kuesioner ke Kabupaten Banyuasin yang terdiri dari sembilan belas Kecamatan. Karateristik responden terdiri dari jenis kelamin, tingkat pendidikan. Sebanyak 93 yang terdiri dari operator ataupun pengguna dari aplikasi Siskeudes yang di ambil secara acak.

Dari hasil distribusi jawaban responden dengan: 50 Laki-laki dan 43 perempuan. Berdasarkan pendidikan terakhir mulai dari SMA sebanyak 84, Diploma 3 sebanyak: 3, dan Strata 1 sebanyak: 5. Karateristik responden berdasarkan dari asal sekolah dapat dilihat pada table 1. Pada tabel 1. merupakan sampel pada penelitian sistem keuangan desa.
Tabel 1. Karateristik Responden Berdasarkan Kecamatan

\begin{tabular}{|c|c|c|}
\hline No & Nama Kecamatan & $\begin{array}{c}\text { Jumlah } \\
\text { Responden }\end{array}$ \\
\hline 1 & Kecamatan Air Salek & 4 \\
\hline 2 & Kecamatan Banyuasin I & 4 \\
\hline 3 & Kecamatan Banyuasin II & 5 \\
\hline 4 & Kecamatan Banyuasin III & 8 \\
\hline 5 & Kecamatan Betung & 3 \\
\hline 6 & Kecamatan Makarti Jaya & 4 \\
\hline 7 & Kecamatan Muara Padang & 5 \\
\hline 8 & Kecamatan Muara Sugihan & 7 \\
\hline 9 & Kecamatan Muara Telang & 5 \\
\hline 10 & Kecamatan Pulau Rimau & 9 \\
\hline 11 & Kecamatan Rambutan & 6 \\
\hline 12 & Kecamatan Rantau Bayur & 6 \\
\hline 13 & Kecamatan Sembawa & 3 \\
\hline 14 & Kecamatan Suak Tapeh & 3 \\
\hline 15 & Kecamatan Talang Kelapa & 4 \\
\hline 16 & Kecamatan Tanjung Lago & 5 \\
\hline 17 & Kecamatan Tungkal Ilir & 4 \\
\hline 18 & Kecamatan Air Kumbang & 5 \\
\hline 19 & Kecamatan Marga Telang & 3 \\
\hline & Total & 93 \\
\hline
\end{tabular}

Penyebaran kuesioner ini disebarkan secara langsung ke pengguna sistem keuangan desa di Kabupaten Banyuasin. Pada Tabel 2 merupakan definisi variable dalam penelitian ini.

Tabel 2. Definisi Variabel Penelitian

\begin{tabular}{|c|c|c|}
\hline Variabel & Indikator & Kode \\
\hline \multirow[t]{3}{*}{ Easy Of Use } & $\begin{array}{l}\text { Apakah mudah mencari } \\
\text { informasi yang anda } \\
\text { butuhkan dalam aplikasi } \\
\text { ini? }\end{array}$ & \multirow[t]{3}{*}{$\mathrm{X} 1$} \\
\hline & $\begin{array}{l}\text { Apakah Aplikasi ini } \\
\text { mudah di akses? }\end{array}$ & \\
\hline & $\begin{array}{lcc}\text { Apakah tools } & \text { dalam } \\
\text { aplikasi ini mudah } \\
\text { digunakan? }\end{array}$ & \\
\hline \multirow[t]{3}{*}{ Customization } & $\begin{array}{l}\text { Apakah tampilan warna } \\
\text { pada aplikasi ini } \\
\text { menarik? }\end{array}$ & \multirow[t]{3}{*}{$\mathrm{X} 2$} \\
\hline & $\begin{array}{|lrr|}\text { Apakah } & \text { tampilan } \\
\text { aplikasi } & \text { ini } & \text { mudah } \\
\text { diingat? } & & \\
\end{array}$ & \\
\hline & $\begin{array}{l}\text { Apakah informasi yang } \\
\text { disajikan dalam aplikasi } \\
\text { ini mudah digunakan? }\end{array}$ & \\
\hline $\begin{array}{l}\text { Download } \\
\text { Delay }\end{array}$ & $\begin{array}{lrr}\text { Apakah } & \text { Halaman } \\
\text { Aplikasi } & \text { ini } & \text { tampil } \\
\text { dengan } & \text { cepat } & \text { setelah }\end{array}$ & X3 \\
\hline
\end{tabular}




\begin{tabular}{|c|c|c|}
\hline & anda klik link-nya? & \\
\hline & $\begin{array}{l}\text { Apakah anda mudah } \\
\text { mengakses informasi } \\
\text { tiap halaman? }\end{array}$ & \\
\hline & $\begin{array}{l}\text { Apakah informasi yang } \\
\text { akan anda butuhkan } \\
\text { dengan mudahnya di } \\
\text { download dari aplikasi } \\
\text { ini? }\end{array}$ & \\
\hline \multirow[t]{4}{*}{ Content } & $\begin{array}{l}\text { Apakah jumlah } \\
\text { informasi yang disajikan } \\
\text { sesuai dengan kebutuhan } \\
\text { anda? }\end{array}$ & \multirow[t]{4}{*}{$\mathrm{X} 4$} \\
\hline & Kelayakan tools & \\
\hline & $\begin{array}{l}\text { Apakah dengan adanya } \\
\text { keragaman informasi } \\
\text { yang disajikan bisa } \\
\text { menarik bagi anda? } \\
\end{array}$ & \\
\hline & $\begin{array}{l}\text { Apakah kalimat } \\
\text { informasi yang disajikan } \\
\text { mudah dimengerti? }\end{array}$ & \\
\hline \multirow{3}{*}{$\begin{array}{c}\text { User } \\
\text { Satisfaction }\end{array}$} & $\begin{array}{l}\text { Apakah anda puas } \\
\text { dengan pelayanan yang } \\
\text { ada pada aplikasi } \\
\text { SISKEUDES ini? }\end{array}$ & \multirow{3}{*}{$\mathrm{Y}$} \\
\hline & $\begin{array}{l}\text { Apakah aplikasi ini } \\
\text { selalu memberikan } \\
\text { informasi yang update? }\end{array}$ & \\
\hline & $\begin{array}{l}\text { Apakah } \text { anda } r \text { puas } \\
\text { dengan aplikasi ini } \\
\text { dengan media gadget } \\
\text { dalam } \\
\text { aplikasi ini? }\end{array}$ & \\
\hline
\end{tabular}

Penelitian ini menggunakan anaslisis regresi berganda yang dimana terdiri dari variable yang berpengaruh dan variable yang dipengaruhi. Dimana terdiri dari variable bebas $(\mathrm{X} 1, \mathrm{X} 2, \mathrm{X} 3$, X4) dan satu variabel terikat (Y). Pada table 3 merupakan hasil dari analisis regresi linear berganda:

Tabel 3. Descriptive Statistics Descriptive Statistics

\begin{tabular}{|l|l|r|rr|}
\hline & Mean & $\begin{array}{c}\text { Std. } \\
\text { Deviation }\end{array}$ & $\mathrm{N}$ & \\
\hline & 2.2241 & .75872 & & 93 \\
& 3.0861 & .25503 & & 93 \\
& 3.1397 & .31598 & & 93 \\
& 3.1040 & .32245 & 93 \\
& 3.0648 & .21626 & & 93 \\
\hline
\end{tabular}

Pada tabel 3 merupakan hasil descriptive Statistics yang dimana terdiri dari mean, Std. Deviation dan N untuk setiap variabel.
Tabel 4. Correlations

\begin{tabular}{|c|c|c|c|c|c|c|}
\hline \multicolumn{7}{|c|}{ Correlations } \\
\hline & & $\gamma$ & $X_{1}$ & $\times 2$ & $x_{3}$ & $X_{4}$ \\
\hline \multirow[t]{5}{*}{ Pearson Correlation } & y & 1.000 & .760 & .789 & .569 & .443 \\
\hline & X1 & 760 & 1.000 & .840 & .771 & .555 \\
\hline & $\times 2$ & .789 & .840 & 1.000 & .638 & .505 \\
\hline & X3 & .569 & .771 & .638 & 1.000 & .632 \\
\hline & X4 & .443 & .555 & .505 & .632 & 1.000 \\
\hline \multirow[t]{5}{*}{ Sig. (1-talled) } & Y & & .000 & .000 & .000 & .000 \\
\hline & $x_{1}$ & .000 & & .000 & .000 & .000 \\
\hline & X2 & .000 & .000 & & .000 & .000 \\
\hline & X3 & .000 & .000 & .000 & & .000 \\
\hline & X4 & .000 & .000 & .000 & .000 & \\
\hline \multirow[t]{5}{*}{ N } & Y & 93 & 93 & 93 & 93 & 93 \\
\hline & X1 & 93 & 93 & 93 & 93 & 93 \\
\hline & X2 & 93 & 93 & 93 & 93 & 93 \\
\hline & X3 & 93 & 93 & 93 & 93 & 93 \\
\hline & X4 & 93 & 93 & 93 & 93 & 93 \\
\hline
\end{tabular}

Pada tabel 4 dapat dijelaskan sebagi berikut:

1. $r$ hitung variabel $\mathrm{X} 1$ dan Variabel $\mathrm{Y}$ (rX1Y) adalah 0,760 . Angka ini menunjukan angka yang kuat antara variabel $\mathrm{X} 1$ dan $\mathrm{Y}$.

2. $r$ hitung variabel $\mathrm{X} 2$ dan Variabel $\mathrm{Y}$ (rX2Y) adalah 0,789. Angka ini menunjukan angka yang kuat antara variabel $\mathrm{X} 2$ dan $\mathrm{Y}$.

3. $r$ hitung variabel X3 dan Variabel Y (rX3Y) adalah 0,569. Angka ini menunjukan angka yang kuat antara variabel $\mathrm{X} 3$ dan $\mathrm{Y}$.

4. $r$ hitung variabel X4 dan Variabel Y (rX4Y) adalah 0,443 . Angka ini menunjukan angka yang kuat antara variabel $\mathrm{X} 4$ dan $\mathrm{Y}$.

5. Sig. (1-tailed) $=0,000$ menunjukan hubungan yang signifikan karena $0,000<0,05$ dimana 0,05 merupakan taraf signifikan. 
Tabel 5. Coefficients

Coefficients ${ }^{\mathrm{a}}$

\begin{tabular}{|c|c|c|c|c|c|}
\hline \multirow[b]{2}{*}{ Model } & \multicolumn{2}{|c|}{ Unstandardized Coefficients } & \multirow{2}{*}{$\begin{array}{l}\text { Standardized } \\
\text { Coefficients } \\
\text { Beta }\end{array}$} & \multirow[b]{2}{*}{ t } & \multirow[b]{2}{*}{ Sig. } \\
\hline & $B$ & Std. Error & & & \\
\hline 1 (Constant) & -4.727 & .736 & & -6.424 & .000 \\
\hline$X_{1}$ & 1.050 & .415 & .353 & 2.530 & .013 \\
\hline$\times 2$ & 1.222 & .279 & .509 & 4.386 & .000 \\
\hline$\times 3$ & -.082 & .251 & .035 & .326 & .745 \\
\hline$X_{4}$ & .042 & .288 & .012 & .145 & .885 \\
\hline
\end{tabular}

a. Dependent Variable: $Y$

Pada tabel 5 dapat diuraikan sebagai berikut:

1. Persamaan regresi $Y=-0,4.727+0,1.050 X 1$ $+0,1.222 \mathrm{X} 2+-0,082 \mathrm{X} 3+0,042 \mathrm{X} 4$.

2. Konstanta sebesar $-0,4.727$ menyatakan bahwa jika tidak ada kenaikan nilai variabel $\mathrm{X} 1, \mathrm{X} 2, \mathrm{X} 3$ dan $\mathrm{X} 4$, nilai variabel $\mathrm{Y}$ adalah $0,4.727$.

3. Koefisien regresi variabel X1 sebesar 0,1.050 menyatakan bahwa setiap penambahan satu nilai pada variabel X1 akan memberikan kenaikan skor sebesar 0,1.050 Koefisien variabel X1, memengaruhi secara signifikan terhadap Variabel Y. Hal ini terlihat dari tingkat signifikan variabel X1 sebesar 0,013 yang lebih kecil dari 0,05

4. Koefisien regresi variabel X2 sebesar 0,1.222 menyatakan bahwa setiap penambahan satu nilai pada variabel X2 akan memberikan kenaikan skor sebesar 0,1.222 Koefisien variabel X2, memengaruhi secara signifikan terhadap Variabel Y. Hal ini terlihat dari tingkat signifikan variabel X2 sebesar 0,000 yang lebih kecil dari 0,05

5. Koefisien regresi variabel X3 sebesar $-0,082$ menyatakan bahwa setiap pengurangan satu nilai pada variabel X3 akan memberikan penurunan skor sebesar -0,082 Koefisien variabel $\mathrm{X} 3$, tidak memengaruhi secara signifikan terhadap Variabel Y. Hal ini terlihat dari tingkat signifikan variabel $\mathrm{X} 3$ sebesar 0,745 yang lebih besar dari 0,05

6. Koefisien regresi variabel $\mathrm{X} 4$ sebesar $-0,042$ menyatakan bahwa setiap penambahan satu nilai pada variabel $\mathrm{X} 4$ akan memberikan kenaikan skor sebesar 0,042 Koefisien variabel $\mathrm{X} 4$, tidak memengaruhi secara signifikan terhadap Variabel $Y$. Hal ini terlihat dari tingkat signifikan variabel $\mathrm{X} 4$ sebesar 0,885 yang lebih besar dari 0,05 .

\section{SIMPULAN DAN SARAN}

Dari hasil penelitian dan pembahasan yang telah dilakukan oleh peneliti disimpulkan bahwa Koefisien regresi variabel X1 sebesar 0,013 yang artinya Koefisien variabel $\mathrm{X} 1$, memengaruhi secara signifikan terhadap Variabel $\mathrm{Y}$, koefisien regresi variabel $\mathrm{X} 2$ sebesar 0,000 yang artinya Koefisien variabel $\mathrm{X} 2$ mempengaruhi secara signifikan terhdap variabel $\mathrm{Y}$, koefisien regresi variabel $\mathrm{X} 3$ sebesar 0,745 yang artinya Koefisien variabel X3 tidak mempengaruhi secara signifikan terhadap variabel Y dikarenakan lebih besar dari 0,05, koefisien regresi variabel X4 sebesar 0,885 yang artinya Koefisien variabel X4 tidak mempengaruhi secara signifikan terhadap variabel Y dikarenakan lebih besar dari 0,05. Persamaan yang didapatkan dari hasil penelitian meliputi: Persamaan regresi $\mathrm{Y}=-0,4.727+$ $0,1.050 \mathrm{X} 1+0,1.222 \mathrm{X} 2+-0,082 \mathrm{X} 3+0,042$ $\mathrm{X} 4$.

\section{UCAPAN TERIMA KASIH}

Ucapan terimakasih penulis sampaikan kepada Pihak Kemenristekditi yang telah memberikan biaya terhadap penelitian ini, penulis ucapkan juga kepada kedua orang tua yang telah memberikan dukungan moril terhadap penelitian ini serta kepada teman-teman dosen yang telah membagikan ilmu kepada peneliti.

\section{REFERENSI}

[1] R, Teguh, Akuntanbilitas Finansial Dalam Pengelolaan Alokasi Dana Desa (ADD) Di Kantor Desa Perangat Selatan Kecamatan Marangkayu Kabupaten Kutai Kartanegara, Journal Administrasi Negara, Volume 3, Nomor 1, 199 - 130, 2015.

[2] S. Khotimah, V. Mayasari, B. Sunarko, F. Ekonomi, D. Bisnis, and U. Jenderal, "EQUILIBRIA PENDIDIKAN Jurnal Ilmiah Pendidikan Ekonomi," Equilibria Pendidilan, vol. 2, no. 2, pp. 45-48, 2017.

[3] Mustakini, "IJIS Indonesian Journal on Information System ISSN 2548-6438," IJIS-Indonesia J. Inf. Syst., vol. 2, no. September 2017, pp. 69-76, 2009. 
[4] W. Handiwidjojo and L. Ernawati, "Pengukuran Tingkat Ketergunaan ( Usability ) Sistem Informasi Keuangan Studi Kasus: Duta Wacana Internal Transaction ( Duwit)," Juisi, vol. 02, no. 01, pp. 49-55, 2016.

[5] R. Rahmawati and S. Anwar, "Analisis Pengukuran Kualitas Layanan Website LP2M UIN Raden Fatah Palembang Menggunakan Metode Webqual 4.0," J. Intelekt. Keislaman, Sos. dan Sains, vol. 7, no. 1, pp. 1-10, 2018.

[6] A. P. Kristianto, M. T. Informatika, D. Magister, T. Informatika, and C. Catur, "Analisis usabilitas sistem informasi driver pt. gojek indonesia berdasarkan pendekatan evaluasi usability heuristik," Semin. Nas. Teknol. Inf. dan Multimed. 2018, pp. 43-48, 2018.

[7] I. G. Andika and C. P. Yanti, "Analisis Evaluasi Aplikasi Augmented Reality Untuk Informasi Kebudayaan Bali Berdasarkan Standar ISO 25010," J. Resist. (Rekayasa Sist. Komputer), vol. 1, no. 1, pp. 34-40, 2018. 